\title{
Study of Control for Mechanical and Optical Properties of Polymeric Optical Materials Considering Molecular Orientation and Dynamics
}

\author{
Shogo NobuKawA ${ }^{\dagger}$ \\ Department of Life Science and Applied Chemistry, Department of Engineering, Nagoya Institute of Technology, \\ Gokiso-cho, Showa-ku, Nagoya, Aichi 466-8555, Japan
}

\begin{abstract}
I reviewed our studies of improvement of mechanical and optical properties in polymeric materials by addition of small-molecules based on orientation correlation and restriction of molecular local dynamics. Birefringence, which is one of important properties for optical applications, is induced by molecular orientation of polymer chains. In order to improve birefringence of stretched films by small additives, we investigated the orientation behavior of the additive molecules in polymer films during stretching based on the nematic interaction theory. We examined the modulus enhancement of polycarbonate (PC) by addition of rod-like small molecules. From the results of mechanical and dielectric relaxation measurements, the modulus improvement was caused by restriction of local dynamics of polymer and rotational motion of additives due to the filling the free volume of PC. Moreover, we found that, based on the photo-elastic theory, the enhanced modulus in PC reduced the photo-elastic birefringence, which must be decreased for optical films.
\end{abstract}

Key Words: Birefringence control / Modulus improvement / Low-mass additive / Molecular orientation / Local dynamics

\section{分子の配向と運動性に基づいた高分子光学材料の力学 および光学特性制御に関する研究}

\section{信川 省吾}

（原稿受理：2020 年 9 月 23 日）

\section{1. はじめに}

フラットパネルディスプレイ, 光学ドライブ, 光学レンズ, 光ファイバーなどの様々な光学機器に高分子材料が利用され ている．近年では，大画面ディスプレイ，スマートフォン， 高解像度カメラ等, 高性能な光学デバイスの登場により, 高 分子材料の光学特性の精密な制御が求められるようになった. 光学特性の一つである複屈折は偏光状態の制御に重要であり, ディスプレイのコントラストや色むらなどにも影響する。こ の時, (光学) 位相差が光の偏光状態を決定する. ここで位 相差 $\left(R_{e}\right)$ は複屈折 $(\Delta n)$ と厚み $(d)$ の積である ${ }^{1)}$.

$$
R_{e}=\Delta n \cdot d
$$

$\Delta n$ は光が透過する媒体中における直交した二方向の屈折率 差 $\left(=n_{1}-n_{2}\right)$ として定義される. $R_{\mathrm{e}}$ がゼロであるフィルム は保護膜に, 特定の值の位相差を持つフィルムは偏光制御用 の位相差フィルムに利用されている。例えば, $R_{e}$ が波長の $1 / 4$ である位相差フィルムは $1 / 4$ 波長板と呼ばれ, 直線偏光

\footnotetext{
†名古屋工業大学 大学院工学研究科 生命・応用化学系プログラム

T466-8555 愛知県名古屋市昭和区御器所町

E-mail : nobukawa@nitech.ac.jp, Tel : +81-52-735-7922
}

を円偏光に変換する性能がある。また, 最近の光学機器は軽 量化, 薄型化が進められており, 薄膜で十分な位相差を確保 するため, 複屈折の増強が求められている.

さらに，無機ガラスに比べると，高分子材料は弾性率や表 面硬度などが低く，アロイ化やコンポジットなどの手法によ る力学強度向上も求められている。しかしながら, 透明性の 観点から有効な手法は限られている.

筆者らは，これまでに透明性の高いガラス状高分子として， ポリカーボネート (PC) やポリメタクリル酸メチル (PMMA), セルロースエステル（CE）に低分子を少量添加 することで, 複屈折や弾性率などの性能向上を検討してきた. 特に, 分子配向や運動性の観点から, 物性制御について解明 を行っている。本稿では, 分子間の配向相関を利用した複屈 折制御, および分子運動抑制による弾性率向上, 光弾性複屈 折抑制について紹介する.

\section{2. 低分子添加剤の配向誘起による 高分子光学フィルムの複屈折制御}

\section{1 高分子の複屈折}

高分子材料の複屈折は, 配向 (Orientation), ガラス (Glass), 形態 (Form) の 3 つの複屈折に分類される ${ }^{2,3)}$. 


$$
\Delta n=\Delta n_{O}+\Delta n_{G}+\Delta n_{F}
$$

配向複屈折 $\Delta n_{O}$ は 3 式で表され, 固有複屈折 $\Delta n^{0}$ と主鎖の配 向度 $F$ に比例する.

$$
\Delta n_{O}=\Delta n^{0} F
$$

固有複屈折は高分子鎖が完全配向した時の複屈折であり, 繰 り返し単位の分極率異方性 $\Delta \alpha$ に比例する ${ }^{4}$.

$$
\Delta n_{O}=\frac{2 \pi}{9} \frac{(\bar{n}+2)^{2}}{\bar{n}} \frac{\rho N_{A}}{M_{0}} \Delta \alpha
$$

ここで, $\rho$ は密度, $M_{0}$ は繰り返し単位の分子量, $N_{\mathrm{A}}$ はアボ ガドロ数である. Table I からわかるように, 一般には, 芳 香環などの分極率異方性の大きな構造を持つほど固有複屈折 が大きくなる。一方で, ポリカーボネート（PC）とポリス チレン（PS）を比較すると，どちらも芳香環を有するにも 関わらず, 複屈折の符号は異なっている。これは, 主鎖に対 する芳香環の結合方向に影響されるためである，さらに，固 有複屈折は繰り返し単位の化学構造で決まり, ガラス転移温 度 $\left(T_{\mathrm{g}}\right)$ とは独立した值である。 なお, 本 2 章では配向複屈 折について説明し, ガラス複屈折は 3 章で述べる。 また, 他 の 2 成分に比べ, 形態複屈折は非晶性高分子ではほとんど無 視できるため, 本稿では説明しない.

3 式で説明したように, 配向複屈折は固有複屈折と配向度 の積であり，延伸条件により複屈折值の制御が可能である。

しかしながら, 配向度 $F$ は-0.5 1.0 の間しか取りえないこ とから, 高分子の単一成分を扱う場合, Table I に示した固 有複屈折が最大值となる。そこで, 共重合 ${ }^{5)}$ や高分子ブレン ド法 ${ }^{6}$ ，低分子添加法-9) による制御が試みられている.

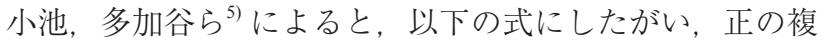
屈折モノマーと負の複屈折モノマーを適切な割合で共重合す ることで, 固有複屈折をゼロにすることが可能である.

$$
\Delta n_{O}=\Delta n_{A}^{0} \phi_{A} F_{A}+\Delta n_{B}^{0}\left(1-\phi_{A}\right) F_{B}
$$

ここで， $\phi$ は体積分率である。例えば, メタクリル酸メチル (MMA）とベンジルメタクリレート（BzMA）を 82:18の比 率で共重合させた高分子は, 任意の延伸比で配向複屈折がゼ ロとなる。一方, 内山, 谷田部ら゙)は, ポリスチレン（PS） とポリフェニレンオキシド（PPO）を71:29の比率でブレン

Table I Intrinsic birefringence $\left(\Delta n^{0}\right)$ and glass transition temperature $\left(T_{\mathrm{g}}\right)$ of various polymers.

\begin{tabular}{|c|c|c|}
\hline PS & $\Delta n^{0}$ & $T_{\mathrm{g}} /{ }^{\circ} \mathrm{C}$ \\
\hline PC & -0.1 & 100 \\
\hline PMMA & 0.106 & 150 \\
\hline PET & -0.0043 & 105 \\
\hline PE & 0.105 & 72 \\
\hline CAP & 0.044 & -68 \\
\hline CTA & 0.014 & 145 \\
\hline PS & -0.04 & 200 \\
\hline
\end{tabular}

PS: polystyrene, PC: polycarbonate, PMMA: poly(methyl methacrylate), PET: poly(ethylene terephthalate), PE: polyethylene, CAP: cellulose acetate propionate, CTA: cellulose triacetate
ドすると配向複屈折が消失すると報告している.

\section{2 低分子添加による配向複屈折制御}

低分子を用いた複屈折制御も検討されている。一般的に, 低分子の配向緩和は高分子に比べて速いため，低分子成分の 配向複屈折への寄与は小さいと予想される。しかし, 実際に は Fig. 1 に示すように, 分子間には配向相関（ネマチック相 互作用 ${ }^{10)}$ がはたらき, 低分子は高分子の主鎖に沿って配向 する，そのため，分極率異方性の大きい低分子を添加すれば, 高分子フィルムの配向複屈折を制御できると考えられる.

高分子 $(p)$ - 低分子添加剂 $(a)$ 間にネマチック相互作用 がはたらく場合, 低分子添加高分子フィルムの配向複屈折 $\Delta n_{O}$ は，次式で表される ${ }^{8)}$.

$$
\Delta n_{O}=\Delta n_{p}+\Delta n_{a d d}=\left[\frac{\phi_{p}\left(\left(1-\epsilon_{p, p}\right) \Delta n_{p}^{0}+\left(1-\phi_{p}\right) \epsilon_{p, a} \Delta n_{a}^{0}\right)}{1-\phi_{p} \epsilon_{p, p}}\right] F_{p}
$$

ここで， $\phi$ は体積分率， $F_{p}$ は高分子の配向度， $\epsilon_{i, j}$ は $i-j$ 間に はたらくネマチック相互作用パラメータである. 6 式の ［］は固有複屈折 $\Delta n^{0}$ に相当する。例えば，Fig. 2 のように， PS に棒状低分子（5CB，5CT）を添加すると, 固有複屈折が 増大する ${ }^{8,11)}$. この結果に 6 式を適用すると, PS-5CB 間のネ マチック相互作用パラメータ $\epsilon_{P S, S C B}$ はおよそ $0.06 \pm 0.01$ と 見積もられ，5CB 分子は PS 鎖にある程度沿って配向するこ とがわかる。また，5CBよりもアスペクト比の大きな $5 \mathrm{CT}$ 分子の場合, $\epsilon_{P S, S C T}$ は $0.08 \pm 0.01$ と $5 \mathrm{CB}$ よりも大きくなる ことがわかった。すなわち, 低分子の長軸が長いほど, マト リックス高分子とのネマチック相互作用（配向相関）が強く, 複屈折を増強させる効果が大きくなる.

また，低分子添加によるセルロースエステルの複屈折制御 の検討からも, ネマチック相互作用は添加剤の構造に依存す ることが判明している ${ }^{9,12,13)}$. CE の一つであるセルロースア セテートプロピオネート（CAP, Fig. 3(A)）に2 種類のポリ

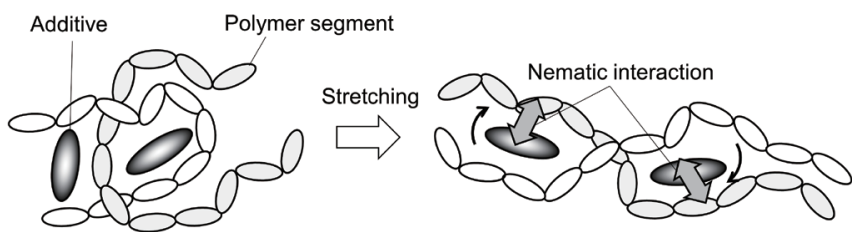

Fig. 1 Schematic illustration of intermolecular orientation correlation due to the nematic interaction.

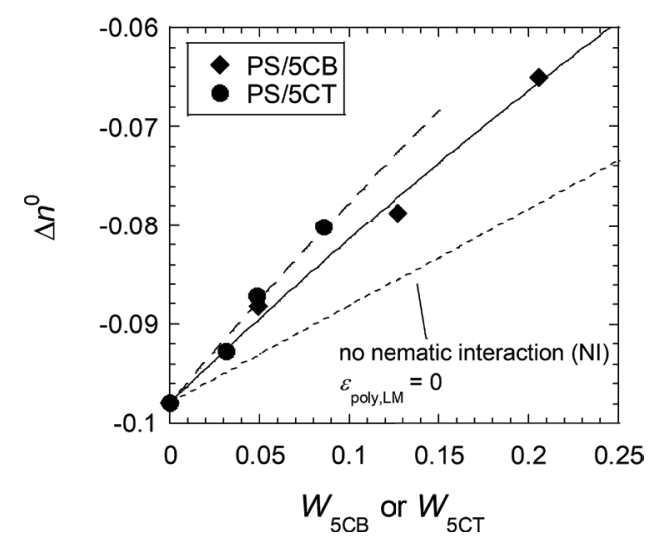

Fig. 2 Concentration dependence of intrinsic birefringence of PS/5CB and PS/5CT blends. (Reprinted with permission from ref. 8) Copyright (C) 2010, American Chemical Society) 
(A)

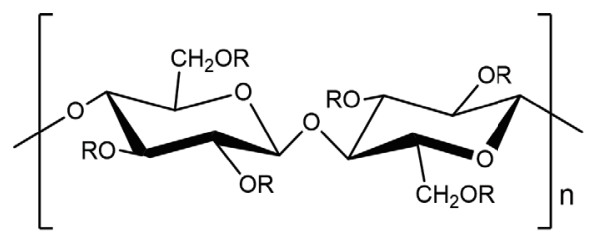

$\mathrm{R}=\mathrm{COCH}_{3}$ (acetyl)

$=\mathrm{COCH}_{2} \mathrm{CH}_{3}$ (propionyl)

(B)<smiles>CCOOC(=O)c1ccc2cc(C(=O)OPO)ccc2c1</smiles>

$\mathrm{R}=\left(\mathrm{CH}_{2}\right)_{2}\left(\mathrm{C}_{2} \mathrm{~Np}\right)$ $\left(\mathrm{CH}_{2}\right)_{6}\left(\mathrm{C}_{6} \mathrm{~Np}\right)$

Fig. 3 Chemical structures of (A) cellulose acetate propionate (CAP) and (B) poly(alkylene naphthalate) oligomers.

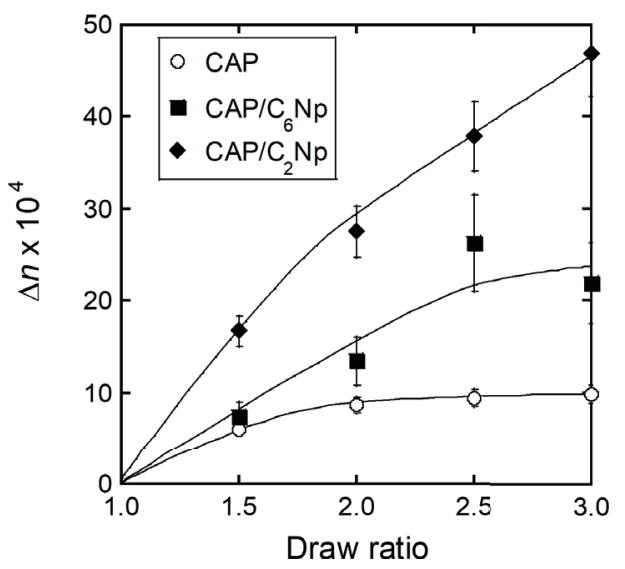

Fig. 4 Orientation birefringence, $\Delta n$, of CAP and CAP/additive (100/ $10 \mathrm{wt} / \mathrm{wt}$ ) films stretched with various draw ratios beyond $T_{\mathrm{g}}$. (Reprinted with permission from ref. 13) Copyright $($ C) 2014, Springer Nature)

エステルナフタレートオリゴマー（Fig. 3(B)）を添加し, 配 向複屈折に与える影響を比較した。 ここで, $\mathrm{C}_{m} \mathrm{~Np}$ の $m$ はア ルキル鎖の炭素数を表しており, 2 種類の添加剤は屈曲性 (剛直性) が異なる. Fig. 4 に, 種々の延伸倍率における複 屈折を示す. CAP 単体と比較すると, どちらの添加剤も複 屈折を向上させるが, $\mathrm{C}_{2} \mathrm{~Np}$ の方がより影響が強いことがわ かる. 6 式に示すように, フィルムの複屈折は CAP と添加 剂の 2 成分の和であり, それぞれの固有複屈折と配向度と関 係している。ただし，同じ延伸倍率では CAP の配向度が同 程度になるように調整しているため, Fig. 4 の差は添加低分 子の複屈折に相当する。 そこで, 添加剂の固有複屈折と配向 度を比較した。

分子シミュレーションによる計算では, 固有複屈折は, $\mathrm{C}_{2} \mathrm{~Np}$ と $\mathrm{C}_{6} \mathrm{~Np}$ でそれぞれ $0.14,0.081^{13)}$ であり, 前者の方が 大きい. 一方, 配向状態を比較するため, 偏光赤外吸収スぺ クトル測定を行い, 赤外二色比から配向度を評価した。

Fig. 5(A) に示すように, 偏光赤外光が延伸方向と平行, 垂 直な状態で, 吸収ピークの大きさに差が確認された。吸光度 の比である赤外二色比から CAP と添加剤の配向度を見積も り, その相関を Fig. 5(B)で比較する. 図より, どちらの系
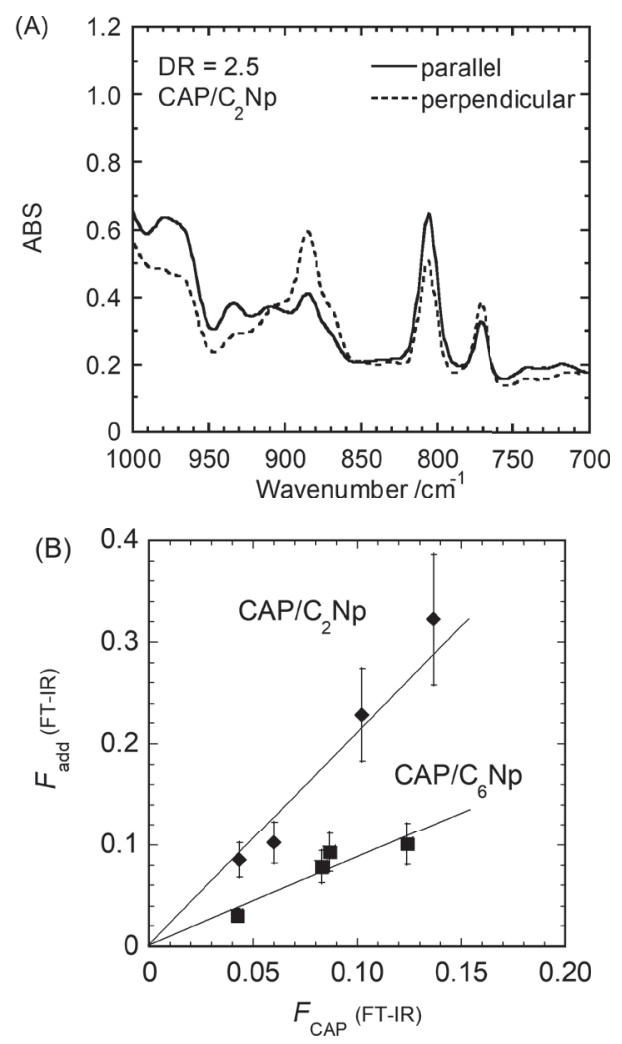

Fig. 5 (A) Polarized FT-IR spectra of $\mathrm{CAP} / \mathrm{C}_{2} \mathrm{~Np}$ stretched film with draw ratio $=2.5$. (B) Relation between orientation functions of additives and CAP estimated with polarized FT-IR spectroscopy. (Reprinted with permission from ref. 13) Copyright (C) 2014, Springer Nature)

も直線関係にあり，添加剤は CAP に沿って配向することが わかる。また, $\mathrm{CAP} / \mathrm{C}_{2} \mathrm{~Np}$ と $\mathrm{CAP} / \mathrm{C}_{6} \mathrm{~Np}$ では配向相関に差が あり, より剛直な構造である $\mathrm{C}_{2} \mathrm{~Np}$ の方が, ネマチック相互 作用は強いことがわかった。

\section{3 複屈折の波長依存性制御}

我々は, 芳香族系化合物をトリアセチルセルロース （CTA）に添加することで, 複屈折の波長依存性が変化する ことも見出している ${ }^{14,15)}$. Fig. 6 に示すように, CTA は負の 複屈折を示し, その絶対值は長波長ほど小さくなる（正分散 性)。広い波長範囲で使用可能な位相差フィルムを設計する 場合, 長波長ほど複屈折の絶対值が大きくなる，いわゆる逆 分散性が必要である。通常, 単一の高分子フィルムでは逆分 散性は達成できない。しかしながら，例えば，CTAにトリ クレジルフォスフェート（TCP）を $5 \mathrm{wt} \%$ の割合で添加し, そのフィルムを $T_{\mathrm{g}}$ 以上で加熱延伸すると, 正の複屈折かつ 逆分散性を示すことが判明した。これは，次で説明するよう に，ネマチック相互作用により CTA 鎖とともに TCP 分子が 配向したことに起因する。

CTAの貧溶媒であるメタノールにフィルムを浸漬し, TCP のみ除去すると, Fig. 6 ののように, CTA 延伸フィルム特 有の負の複屈折かつ正波長分散性が観測された。全体の複屈 折は CTA と TCPの 2 成分の和であることを踏まえると, TCP 成分の複屈折は Fig. 6 の $\square$ で示され, 正の複屈折かつ正 分散性であることがわかる。すなわち, TCP 分子はネマ チック相互作用により CTA 鎖に沿って配向することで正の 複屈折を発現し， CTAの負の複屈折とのバランスで，ブレ ンドフィルムは正の複屈折，逆分散性を示したと考えられる. 


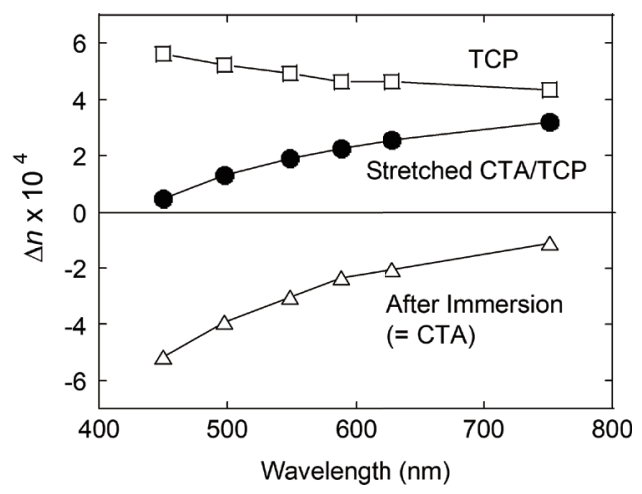

Fig. 6 Wavelength dependence of orientation birefringence for CTA/TCP stretched film. Opened symbols represent the component birefringence for CTA and TCP. (Reproduced with permission from ref. 14) Copyright (C) 2011 American Chemical Society)

\section{4 分子配向と面内複屈折 /面外複屈折の関係}

次に, 低分子添加による 3 次元の屈折率制御について紹介 する。ここまで述べてきた複屈折はフィルムの面内 $(x-y)$ の屈折率差である。実際に, 位相差フィルムを液晶ディスプ レイで使用する際, 斜め方向の視野を確保するため, フィル 厶の面外（厚み方向， $x-z, y-z$ ) の屈折率差も制御する必要が ある. 面内複屈折 $\Delta n_{\mathrm{in}}$, 面外複屈折 $\Delta n_{\mathrm{th}}$ はそれぞれ次式のよ うに定義される。

$$
\begin{aligned}
& \Delta n_{\text {in }}=n_{x}-n_{y} \\
& \Delta n_{t h}=\left(n_{x}+n_{y}\right) / n_{z}
\end{aligned}
$$

通常, $T_{\mathrm{g}}$ 以上で自由端（幅固定無し）の一軸延伸（延伸 方向： $x$ 軸）を行うと $y, z$ 軸の屈折率 $\left(n_{y}, n_{z}\right)$ が一致するた め, 面内と面外の複屈折の関係は, $\Delta n_{t h}=\Delta n_{i n} / 2$ となる。一 例として, CTA 延伸フィルムの $\Delta n_{\text {in }}$ と $\Delta n_{\text {th }}$ の波長依存性を Fig. 7(A)に示す.どの波長でも両者の比はおおむね 2：1で あり, 自由端一軸延伸の挙動と一致している. 一方, 棒状分 子である $5 \mathrm{CB}$ を $5 \mathrm{wt} \%$ 添加し, 同じ条件で加熱延伸を実施 したところ, $\Delta n_{t h} \approx \Delta n_{i n}$ となり, CTA 単体と異なる挙動を示 した ${ }^{16)}$.これは, 棒状分子である $5 \mathrm{CB}$ の 3 次元的な配向が 一軸延伸にしたがっていないためと考え, $\Delta n_{\mathrm{in}}$ と $\Delta n_{\mathrm{th}}$ の值か ら $x, y, z$ 軸の屈折率 $\left(n_{x}, n_{y}, n_{z}\right)$ を見積もった. その結果を Fig. 7 (B) に示す. CTA 単体では $n_{y}=n_{z}$ であるが, CTA $/ 5 \mathrm{CB}$ では $n_{x}>n_{y}>n_{z}$ であることから, Fig. 8 のように, CTA 中で $5 \mathrm{CB}$ 分子は延伸方向 ( $x$ 軸) に配向するとともに, フィルム の厚み方向 $(z$ 軸) には拘束された状態であることが示唆さ れた。

上記の $\mathrm{CTA} / 5 \mathrm{CB}$ の配向挙動は, 幅固定の平面伸長モード において観測されるものであることから，本系では単純な一 軸延伸ではない可能性も考えられる. しかしながら, 現時点 では CTA/5CB の複屈折挙動が自由端一軸延伸にしたがわな い詳しいメカニズムは判明していない.

以上のように，本節では，低分子添加による高分子フィル ムの複屈折制御について, 分子配向相関, 波長依存性, 3 次 元配向の観点から解説した。ここで紹介した以外にも，高分 子と低分子の配向挙動の差や, 光異性化を利用した複屈折制 御などについても検討を行っている.
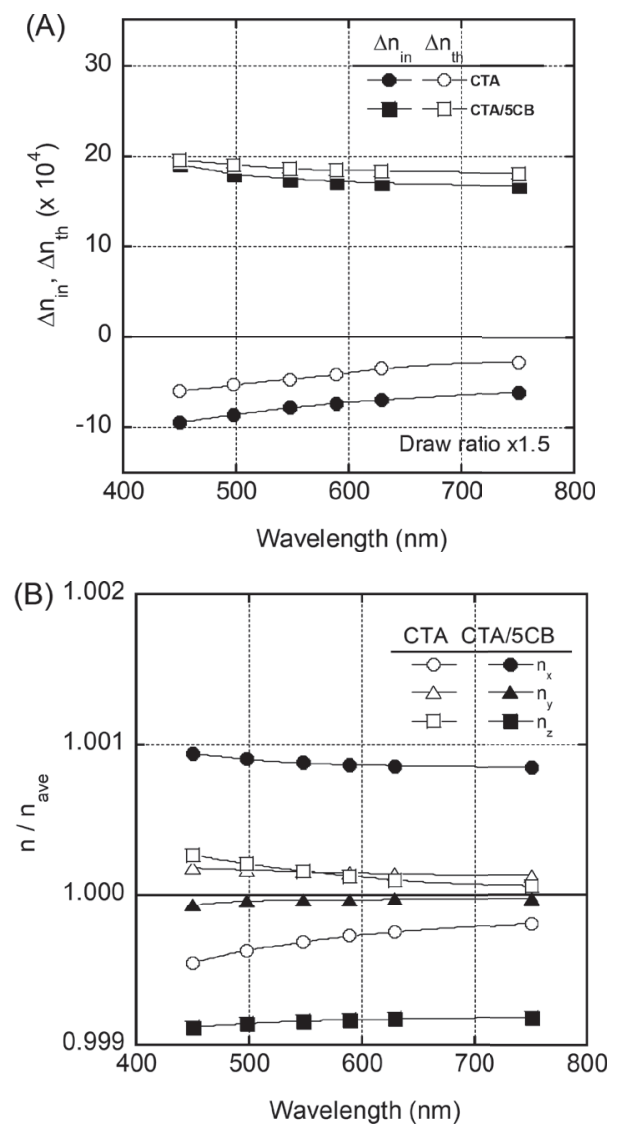

Fig. 7 (A) Wavelength dependence of in-plane and out-of-plane birefringence $\left(\Delta n_{\text {in }}\right.$ and $\Delta n_{\text {th }}$ ) for CTA and CTA/5CB stretched films. (B) Refractive indices in $x, y, z$ axes of stretched films estimated from data (A). (Reprinted with permission from ref. 16). Copyright (C) 2014 Elsevier Ltd. All rights reserved.)

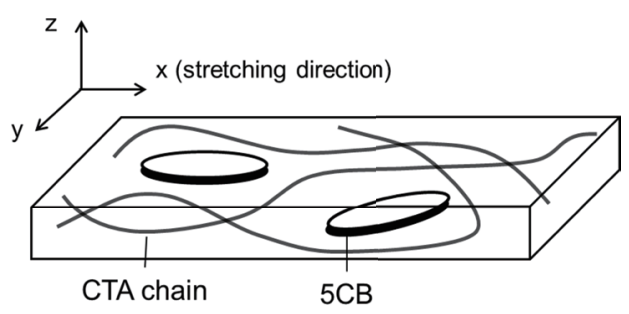

Fig. 8 Schematic representation of in-plane orientation of $5 \mathrm{CB}$ molecule in CTA uni-axially stretched film.

\section{3. 低分子添加による弾性率向上および複屈折抑制}

\section{1 芳香族分子添加による弾性率向上（逆可塑化）}

PC（Fig. 9）は透明性, 耐熱性, 耐衝撃性に優れる事から, 光学フィルムに加え, 自動車用空ガラスなどの無機ガラス代 替として期待されている。しかしながら, 引張弾性率が $1.8 \mathrm{GPa}$ 程度とアクリルガラスの $3 \mathrm{GPa} よ り も$ 低く, 芳香環 を持つため複屈折が大きいことが問題となっている.

PC に低分子化合物を添加すると, ガラス状態（室温）の 弾性率が向上することが知られている ${ }^{17,18)}$ 。本現象は逆可塑 化と呼ばれており，低分子は分子レベルで分散しているため， 光学フィルムに重要な透明性も維持される。低分子化合物自 身が, 光学異方性を有する場合, 複屈折にも影響すると考え られる。そこで，我々は種々の低分子を $10 \mathrm{wt} \%$ 以下の濃度 で PCに添加し, 弾性率向上およびそのメカニズム解明と, ガラス複屈折への影響について検討した。 


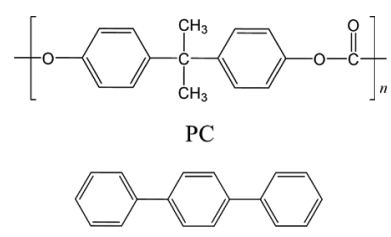

$p$-tPh

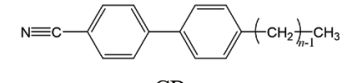

$n \mathrm{CB}$

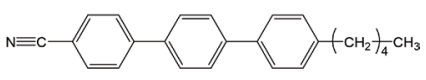

$5 \mathrm{CT}$

Fig. 9 Chemical structures of $\mathrm{PC}$ and additives ( $p$-tPh, $n \mathrm{CB}$ and $5 \mathrm{CT})$ used in this study.

\section{2 弾性率向上と分子運動の関係}

Fig. 10 に $\mathrm{PC}$ および $\mathrm{PC} / p$ - $\mathrm{tPh}(10 \mathrm{wt} \%)$ の貯蔵弾性率 $E^{\prime}$ と損失弾性率 $E^{\prime \prime}$ の温度依存性を示す。 $p$-tPh を添加すること で， $\alpha$ 緩和のピーク温度が低温側にシフトしており， $T_{\mathrm{g}}$ が低 下していることがわかる ${ }^{19,20)}$. 一方, $-100 \sim 100{ }^{\circ} \mathrm{C}$ の範囲で $E^{\prime}$ は増加している。この現象が逆可塑化である。ささらに, $E^{\prime \prime}$ に着目すると, $p$ - $\mathrm{tPh}$ を添加することで, $-100{ }^{\circ} \mathrm{C}$ 付近に 観測される $\gamma$ 緩和が抑制されるとともに， $50 \sim 100{ }^{\circ} \mathrm{C}$ に新た な $\beta$ 緩和が出現することがわかる. $-100{ }^{\circ} \mathrm{C}$ 付近の $\gamma$ 緩和は, $\mathrm{PC}$ 中のフェニレン基のフリップ運動 ${ }^{21)}$ や, 分子鎖間のス リップなどの局所運動 ${ }^{22}$ を反映すると報告されており, 上 述の結果は PC 鎖の局所運動（ $\gamma$ 緩和）が抑制されたことを 示している。この $\gamma$ 緩和の抑制により室温近傍の $E^{\prime}$ が増大 すると考えられる。 また, 室温〜 $T_{\mathrm{g}}$ の温度域で熱機械分析 を実施したところ， $p$-tPh の添加により線膨張係数が $10 \%$ 程 度低下することも確認された。熱澎張は分子運動性を反映し ており, ガラス状態での自由体積が低減していることが示唆 されている。

一般に，低分子を添加すると高分子の $T_{\mathrm{g}}$ は低下し，弾性 率も低くなる。これは, 高分子に比べて低分子の運動性が高 いため, 高分子の局所運動やセグメント（ミクロブラウン） 運動を活性化するためである。本系でも $T_{\mathrm{g}}$ は低下するもの の, 室温の弾性率は向上した。すなわち, $\mathrm{PC}$ 中の低分子の 運動性は，一般的な高分子/低分子系と異なる可能性がある. そこで, 我々は力学緩和と誘電緩和を組み合わせることで,

$\mathrm{PC}$ と低分子ダイナミクスの相関から, 弾性率向上のメカニ ズム解明を試みた。

通常，低分子が少量含まれている場合，ガラス状高分子の 力学緩和測定では, 観測される緩和のほとんどは高分子成分 に由来し, 低分子の緩和は観測されない, 一方, 誘電緩和で

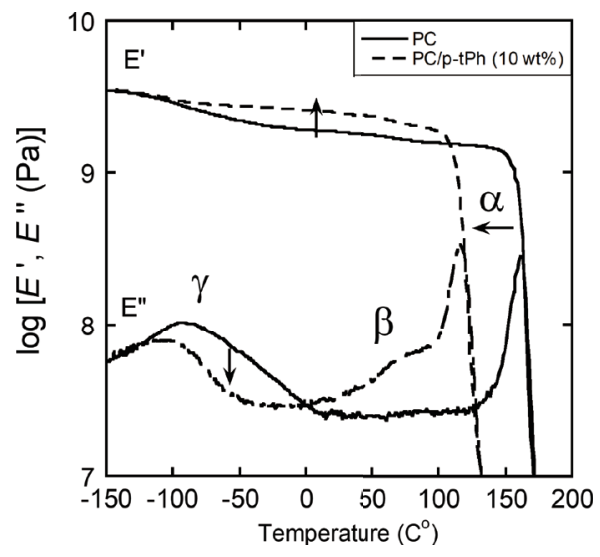

Fig. 10 Improvement of storage modulus at room temperature for PC containing small additive $(p$-tPh). Relation between modulus improvement and local dynamics of PC is also indicated. (Reprinted with permission from ref. 19) Copyright (C) 2013, American Chemical Society)

は電気双極子の配向緩和が観測され, Onsagerの理論 ${ }^{23)} に よ$ ると, その緩和強度 $(\Delta \varepsilon)$ は各成分の体積分率 $\phi$ と, 双極 子モーメント $\mu$ の二乗に比例する.

$$
\Delta \varepsilon \propto \phi \mu^{2}
$$

この式から，マトリックス高分子に比べて双極子モーメント が 10 倍以上大きい低分子では，その緩和強度は 100 倍以上 になるため, 添加濃度が $5 \mathrm{wt} \%$ 程度でも誘電緩和測定では 強い緩和として観測されることがわかる。しかしながら， $p$-tPh は対称な構造を持ち無極性分子であるため, その双極 子モーメントはゼロである。そこで，大きな極性基であるシ アノ基を有する，4-プロピル-4-シアノビフェニル（3CB, Fig. 9) を $p$ - $\mathrm{tPh}$ の代わりに PCに添加し, 力学緩和および誘 電緩和測定を実施した。

Fig. 11 に, $\mathrm{PC}, \mathrm{PC} / p$ - $\mathrm{Phh}(5 \mathrm{wt} \%), \mathrm{PC} / 3 \mathrm{CB}(5 \mathrm{wt} \%)$ の $(\mathrm{A})$ 力学緩和, および $(\mathrm{B})$ 誘電緩和測定の結果を示す ${ }^{24}$. $3 \mathrm{CB}$ の 長軸の長さは $1.22 \mathrm{~nm}$ であり, $3 \mathrm{CB} の 1.35 \mathrm{~nm}$ に近い. 力学 緩和（DMA）の結果を見ると, $\mathrm{PC} / 3 \mathrm{CB}$ は $\mathrm{PC} / p-\mathrm{tPh}$ と同じ $E^{\prime}, E^{\prime \prime}$ の温度依存性を示すことから， PC の局所運動抑制効 果は, $3 \mathrm{CB}$ と $p$ - $\mathrm{tPh}$ で同程度であることがわかる，次に，誘 電緩和の結果を比較する。 $\mathrm{PC}, \mathrm{PC} / p-\mathrm{tPh} の$ 誘電損失 $\varepsilon^{\prime \prime}$ は, 力学緩和の $E^{\prime \prime} の$ 温度依存性とよく一致している。これは, 無極性分子である $p$-tPh の回転運動は誘電緩和では観測され ず, $\varepsilon^{\prime \prime}$ と $E^{\prime \prime}$ の結果に表れる緩和は，PCのセグメント運動
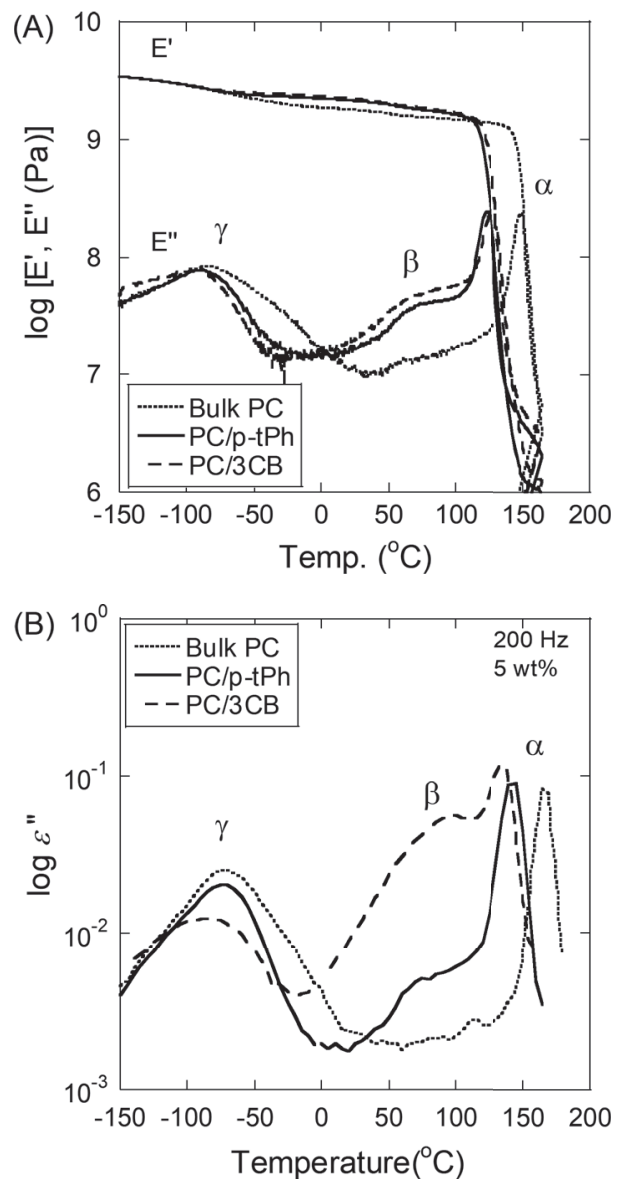

Fig. 11 Temperature dependence of (A) storage and loss moduli ( $E^{\prime}$ and $\left.E^{\prime \prime}\right)$, and $(\mathrm{B})$ dielectric loss $\left(\varepsilon^{\prime \prime}\right)$ for $\mathrm{PC}, \mathrm{PC} / p$-tPh and $\mathrm{PC} / 3 \mathrm{CB}$. (Reprinted with permission from ref. 24) Copyright (C) 2019 The Society of Rheology, Japan) 
および局所運動を反映しているためである。一方， $\mathrm{PC} / 3 \mathrm{CB}$ では, 誘電緩和測定において $\beta$ 緩和が強く観測されている。 ここで, $\mathrm{PC}$ の緩和は $\mathrm{PC} / p$ - $\mathrm{tPh}$ と $\mathrm{PC} / 3 \mathrm{CB}$ で同じであること を考慮すると, 大きな $\beta$ 緩和は $3 \mathrm{CB}$ の長軸の回転運動に帰 属できる。また, $\mathrm{PC} / p-\mathrm{tPh}$ と比べると, $\gamma$ 緩和領域において, $\mathrm{PC} / 3 \mathrm{CB}$ の $\varepsilon^{\prime \prime}$ の緩和ピークはわずかに低下している。詳細は まだ明らかになっていないが，PCの電気双極子を打ち消す ように，3CB 分子が配列している可能性がある.

このように，低分子添加による PCの逆可塑化現象におい て，PCの局所運動が抑制されるだけでなく，低分子自身の 運動性も低下することが明らかになった。また，緩和時間の 温度依存性から, 低分子の $\beta$ 緩和の活性化エネルギー $\left(E_{\mathrm{a}}\right)$ を見積もったところ, $132 \mathrm{~kJ} / \mathrm{mol}$ という值が得られた。 (Table II) 力学緩和における $\beta$ 緩和が小さいために正確な值 は評価できていないが, バルク $\mathrm{PC} の \gamma$ 緩和の $E_{\mathrm{a}}$ が $43 \mathrm{~kJ} /$ $\mathrm{mol}$ であることから, $\mathrm{PC} の \beta$ 緩和の $E_{\mathrm{a}}$ は, $50 \sim 150 \mathrm{~kJ} / \mathrm{mol}$ 程度と推測すると, 低分子の $\beta$ 緩和に近い值となる。 $(\alpha$ 緩 和の $E_{\mathrm{a}}: 100 \sim 300 \mathrm{~kJ} / \mathrm{mol}$ よりは小さい) したがって, 逆可塑 化系において， $\beta$ 緩和領域においては，PCの局所運動と低 分子の長軸回転は協同的であると結論づけられる.

\section{3 弾性率向上に対する分子サイズの影響}

次に, 低分子の長軸サイズが PC の弾性率向上に与える影 響を調べるため，3CBの他に，シアノビフェニル（0CB， Fig. 9), 4-メチル4'-シアノビフェニル (1CB, Fig. 9), 4-ペンチル-4”-シアノターフェニル（5CT, Fig. 9）を添加 したPCについて力学緩和測定を実施した。 Fig. 12 に，いく

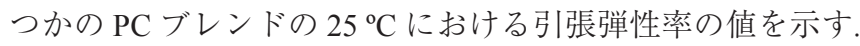
低分子の濃度は $5 \mathrm{wt} \%$ である。 $0 \mathrm{CB} \rightarrow 5 \mathrm{CT}$ の順に分子サイ ズが大きくなる、 $\mathrm{PC} / 0 \mathrm{CB}, \mathrm{PC} / 1 \mathrm{CB}, \mathrm{PC} / 3 \mathrm{CB}$ を添加した $\mathrm{PC}$ は, $\mathrm{PC} / p$-tPh と同程度の弾性率值を示すが, $\mathrm{PC} / 5 \mathrm{CT}$ はわず かに低い值となった ${ }^{24)}$

Inglefieldら ${ }^{25,26)}$ は, プロトンスピン拡散による ${ }^{31} \mathrm{P}$ 固体 NMR 測定から, 低分子添加 PC のガラス構造のドメインサ イズを評価し， 1.1〜 1.3 nm と報告している，ここで，弾性 率に対する影響が変化したサイズと比較する. $3 \mathrm{CB}$ と $5 \mathrm{CT}$ の長軸サイズはそれぞれ 1.22, $1.67 \mathrm{~nm}$ であり, 5CT はガラ スのドメインサイズよりも大きい.すなわち, ガラスのドメ インサイズを超える低分子では, PCの運動の抑制が十分に 達成できず，弾性率への効果が小さくなると考えられる.

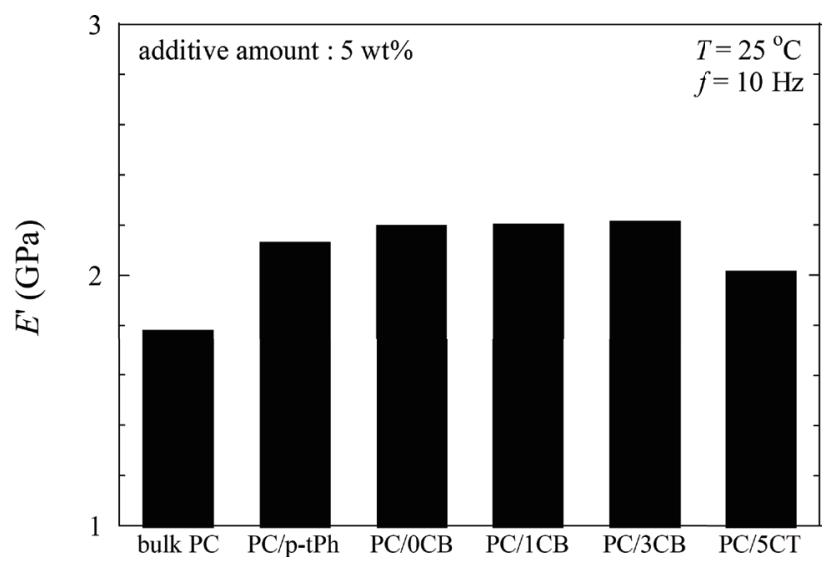

Fig. $12 E^{\prime}$ at $25^{\circ} \mathrm{C}$ of $\mathrm{PC}$ and $\mathrm{PC} /$ additive blends. (Reprinted with permission from ref. 24) Copyright (C) 2019 The Society of Rheology, Japan)

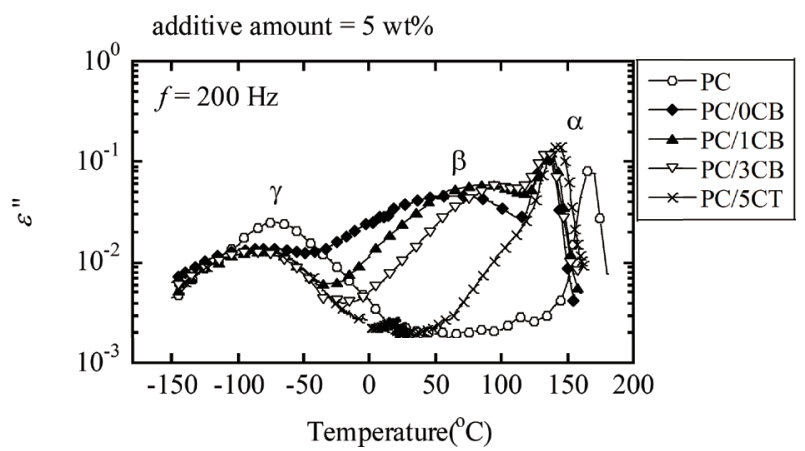

Fig. 13 Comparison of dielectric relaxation in $\varepsilon^{\prime \prime}$ for $\mathrm{PC}$ and $\mathrm{PC} /$ additive blends. (Reprinted with permission from ref. 24) Copyright (C) 2019 The Society of Rheology, Japan)

次に, 誘電緩和測定から, 分子サイズと低分子の運動の関 係を調べた。 Fig. 13 に $\mathrm{PC}, \mathrm{PC} / n \mathrm{CB}, \mathrm{PC} / 5 \mathrm{CT} の \varepsilon^{\prime \prime}$ の温度依 存性を比較する。 $\gamma$ 緩和にはほとんど差は確認されないが, $\beta$ 緩和はサイズの小さな低分子（0CBや1CB）ほど，緩和分 布が広がることがわかる。ささらに各緩和の $E_{\mathrm{a}}$ (Table II）を 見積もると， $\gamma$ 緩和では $45 \sim 69 \mathrm{~kJ} / \mathrm{mol}$ でほぼ一定で, バル ク $\mathrm{PC}$ の值 $(43 \mathrm{~kJ} / \mathrm{mol})$ とも一致した。一方, $\beta$ 緩和では $0 \mathrm{CB}, 1 \mathrm{CB}, 3 \mathrm{CB}$ で $72 ， 84 ， 132 \mathrm{~kJ} / \mathrm{mol}$ と分子サイズが大き くなるほど $E_{\mathrm{a}}$ は増大した。低分子添加 PCの $\gamma$ 緩和は，抑制 されずに残った $\mathrm{PC}$ の局所運動であると考えると, $\gamma$ 緩和の $E_{\mathrm{a}}$ は妥当である。また, 低分子（長軸）の回転運動が $\beta$ 緩 和として観測されていることから， $E_{\mathrm{a}}$ の結果は大きな低分 子ほど PCからの束縛を強く受けると考えられる.

\section{4 低分子添加によるガラス複屈折抑制}

2 章では低分子添加による配向複屈折制御を説明したが, 本 3 章ではガラス状態で発現する光弾性複屈折の抑制につい て紹介する，2式で，高分子の複屈折には，配向，ガラス， 形態の 3 つの起源があると述べた。このうち，ガラス複屈折 $\Delta n_{G}$ は光弾性複屈折とも呼ばれ，ガラス（固体）状態でわず かなひずみによって生じる複屈折のことである. 光弾性則に よると, $\Delta n_{G}$ は次式のように応力 $\sigma$ に比例して発現する ${ }^{27)}$.

$$
\Delta n_{G}=C_{p h} \sigma
$$

ここで, $C_{\mathrm{ph}}$ は光弾性係数であり, 芳香環などの分極率異方 性の大きな官能基, 結合を持つほど大きい值を示す。また, $\mathrm{PC}$ の $C_{\mathrm{ph}}$ は $100 \times 10^{-12} \mathrm{~Pa}^{-1}$ であり, 同じガラス状高分子で あるポリスチレン $\left(\mathrm{PS}, 10 \times 10^{-12} \mathrm{~Pa}^{-1}\right)$ やポリメタクリル酸 メチル $\left(\mathrm{PMMA},-4 \times 10^{-12} \mathrm{~Pa}^{-1}\right)$ と比べると 1〜2桁程度大 きい. そのため, $\mathrm{PC}$ を光学フィルムなどに用いる場合, わ ずかな応力やひずみで複屈折が変動し, 偏光制御に大きく影

Table II $E_{\mathrm{a}}$ values of $\beta$ and $\gamma$ relaxations for PC and PC/additive blends.

\begin{tabular}{lccc}
\hline & $\begin{array}{c}E_{\mathrm{a}}(\mathrm{kJ} / \mathrm{mol}) \\
(\gamma \text { relaxation in DMA })\end{array}$ & $\begin{array}{c}E_{\mathrm{a}}(\mathrm{kJ} / \mathrm{mol}) \\
(\gamma \text { relaxation in DR })\end{array}$ & $\begin{array}{c}E_{\mathrm{a}}(\mathrm{kJ} / \mathrm{mol}) \\
(\beta \text { relaxation in DR })\end{array}$ \\
\hline $\mathrm{PC}$ & $42.8 \pm 4.5$ & $49.3 \pm 1.4$ & - \\
$\mathrm{PC} / 0 \mathrm{CB}$ & $54.7 \pm 3.3$ & $53.8 \pm 5.1$ & $71.6 \pm 1.5$ \\
$\mathrm{PC} / 1 \mathrm{CB}$ & $69.3 \pm 16.1$ & $52.4 \pm 1.6$ & $83.7 \pm 4.2$ \\
$\mathrm{PC} / 3 \mathrm{CB}$ & $45.3 \pm 3.8$ & $47.0 \pm 1.1$ & $132.4 \pm 4.7$ \\
$\mathrm{PC} / 5 \mathrm{CT}$ & $59.9 \pm 11.0$ & $53.7 \pm 0.7$ & - \\
\hline
\end{tabular}



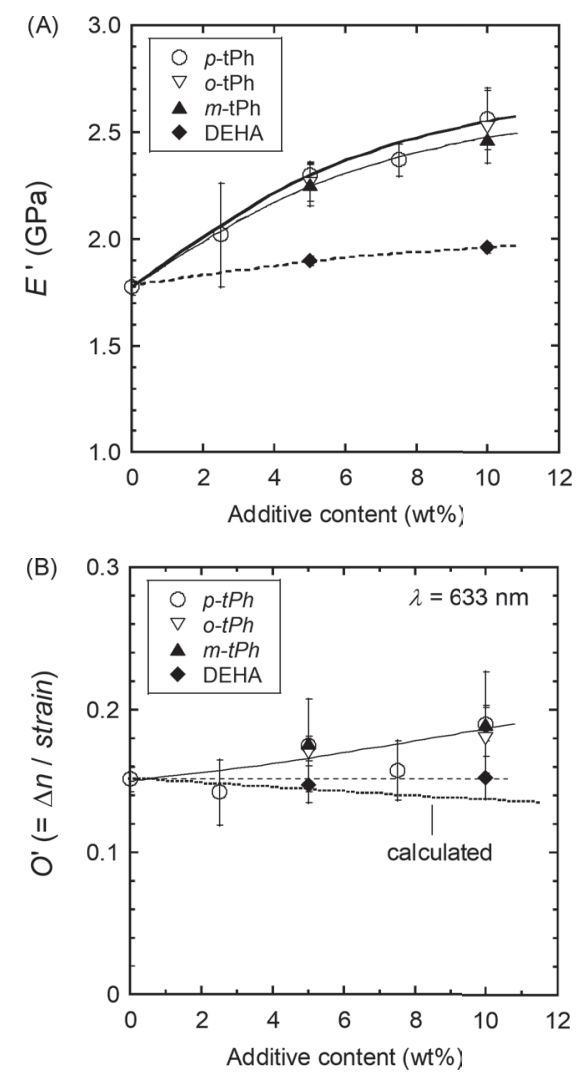

Fig. 14 Concentration dependence of (A) $E^{\prime}$ and (B) strain-optical coefficient $\left(O^{\prime}\right)$ at $25^{\circ} \mathrm{C}$ for $\mathrm{PC}$ and $\mathrm{PC} /$ additive blends. (Reprinted with permission from ref. 28) Copyright (C) 2017 Wiley Periodicals, Inc.)

響する.

一般に, $C_{\mathrm{ph}}$ の值は高分子の繰り返し単位の構造で決まり, 特に $\mathrm{PC}$ のように大きな $C_{\mathrm{ph}}$ を抑制することは難しいと考え られてきた。我々は，低分子添加によるPCの逆可塑化にお いて, 10 式の応力 (=弾性率 $\times$ ひずみ) のみが向上し, 左 辺の複屈折が変化しなければ, 必然的に $C_{\mathrm{ph}}$ が低減できるの ではないかと考えた。 そこで, ターフェニル（tPh）の $3 つ$ の位置異性体 $(o-\mathrm{tPh}, m-\mathrm{tPh}, p-\mathrm{tPh})$ およびジ（2-エチルへ キシル）アジペート（DEHA）をPCに添加し，弾性率およ び光弾性係数への影響を調べた ${ }^{28)}$. DEHA は柔軟なアルキル 基を持つことから逆可塑化の効果が小さいと考え, 比較のた め用いた。

Fig. $14(\mathrm{~A})$ に室温 $\left(25^{\circ} \mathrm{C}\right)$ における弾性率と添加量の関係 を示す．わずかに $p$ - $\mathrm{tPh}$ の効果が高いが，3つの位置異性体 $(o-\mathrm{tPh}, m-\mathrm{tPh}, p-\mathrm{tPh})$ は弾性率を同程度に向上させている. 一方, DEHA は弾性率の増加はわずかであった。

次に光弾性複屈折を比較する。しかしながら, 光弾性複屈 折はひずみ量に依存するため, ひずみで除した值, ひずみ光 学係数 $O\left(=\Delta n_{G} /\right.$ strain $)$ 用いて議論する. 10 式の両辺をひ ずみで除して， $C_{\mathrm{ph}}$ に対する式を導出すると,

$$
C_{p h}=O / E
$$

が得られる. Fig. 14(B)で各 PCブレンドの $O$ を比較する. DEHA を添加した場合， $O$ はほぼ変化しないが，3つの $\mathrm{tPh}$ を添加すると増加傾向を示すことがわかる. 光弾性複屈折は 応力に比例して発生するため, 5 式のような配向複屈折の加 成性の式は示せないが，添加低分子の分極率異方性から定性

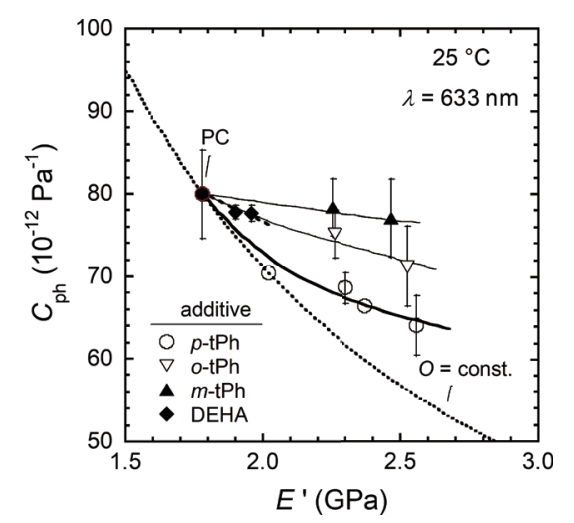

Fig. 15 Relation between $E^{\prime}$ and photo-elastic coefficient $\left(C_{\mathrm{ph}}\right)$ in PC/additive blends, which is systems of modulus improvement. (Reprinted with permission from ref. 28) Copyright (C) 2017 Wiley Periodicals, Inc.)

的な説明は可能である. tPh は 3 つの芳香環がつながった構 造である一方で, DEHA は大きな分極率異方性は持たない. したがって，ひずみ（応力）を印加した際，低分子の構造由 来の複屈折は, $\mathrm{tPh}>\mathrm{DEHA}$ となったと考えられる.

Fig. 14(A)より, tPh 添加で弾性率 $(E)$ は $1.8 \mathrm{GPa}$ から $2.6 \mathrm{GPa}$ まで 1.5 倍に増加しているのに対し， $O$ は 0.15 から 0.18 ま で 1.2 倍であり増加率は低い. この増加率の差を考慮すると, 光弾性係数 $C_{\mathrm{ph}}$ は低減すると考えられる. そこで, 逆可塑化 の影響を定量的に比較するため, $C_{\mathrm{ph}}$ を $E$ に対してプロット する（Fig. 15）。図より，DEHA を添加しても弾性率はほと んど向上せず, $C_{\mathrm{ph}}$ の低減も小さくなっている. 一方, $\mathrm{tPh}$ について， $C_{\mathrm{ph}}$ の低下は $m$ - $\mathrm{tPh}<o$ - $\mathrm{tPh}<p$ - $\mathrm{tPh}$ の順に大きく なった。これは, 3 つの位置異性体で弾性率の増加傾向と一 致していることから, 逆可塑化が $C_{\mathrm{ph}}$ の低減の主要因になっ ていることを示している。

以上より, 低分子添加による弾性率向上を利用すれば, $\mathrm{PC}$ の光弾性係数が抑制されることが示された．特に，3つ の位置異性体の比較により, 剛直な構造の低分子ほど弾性率 が増大し, 光弾性係数が抑制できることも明らかとなった.

\section{4. おわりに}

本稿では，筆者らがこれまでに行った低分子添加による複 屈折および力学物性制御に関する研究を概説した。近年, 開 発が目覚ましいスマートフォンやディスプレイなどの光学機 器において複屈折は重要な物性值である. 分子間の配向相関 を利用すれば，これまで低複屈折であった高分子材料でも高 複屈折化が可能である. また, 表面硬度や剛性が低いガラス 状高分子でも, 分子構造がマッチした低分子を添加すれば, 自由体積や分子運動が抑制され，高弾性化が期待できる。さ らに, 光弾性則に基づいて, 高弾性化に伴うガラス複屈折の 低減も可能である.

低分子を高分子に添加する手法は古くから実施されている が, 力学物性, 光学物性, 電気化学物性などの材料物性を, 分子間相互作用や配向，分子ダイナミクスなどと結び付けた 理解は十分に進んでいない. 今後は, 分子レベルでの情報を より深く理解し, 材料物性と関連付けた研究を進める必要が ある。 


\section{謝 辞}

この度は栄誉ある日本レオロジー学会奨励賞を賜り, 大変 光栄に存じます。本稿で紹介した研究は, 山口政之先生（北 陸先端科学技術大学院大学), 猪股克弘先生 (名古屋工業大 学), Abd Manaf Mohd Edeezoy 博士, Kultida Songsurang 博士, 宮川あずさ博士，島田光星博士，林拓希氏，青木祥彦氏，福 井芳春氏，蓮沼誠紀氏，前田真衣氏をはじめ, 多くの方との 共同研究です。研究の一部に対して, JSPS 科学研究費補助 金, 小笠原科学技術振興財団, 京都技術科学センター, スズ キ財団，日比科学技術振興財団のご支援をいただきました。 この場を借りて, 御礼申し上げます。筆者の学生時代（大阪 大学) の指導教員である浦川理先生, 井上正志先生, 四方俊 幸先生をはじめ, 日本レオロジー学会の皆様には, 多くのご 助言，ご指導を頂き，心より御礼申し上げます。また，日々 の研究活動を支えてくれた家族に感謝いたします。

\section{REFERENCES}

1) Stein RS, Onogi S, Sasaguri K, Keedy DA, J Appl Phys, 34, 80 (1963).

2) Saito H, Inoue T, J Polym Sci Part-B Polym Phys, 25, 1629 (1987).

3) Inoue T, Okamoto H, Osaki K, Macromolecules, 24, 5670 (1991).

4) Ward IM, "Structure and Properties of Oriented Polymers", (1997), Chapman \& Hall, London.

5) Tagaya A, Ohkita H, Harada T, Ishibashi K, Koike Y, Macromolecules, 39, 3019 (2006).

6) Uchiyama A, Yatabe T, Japan J App Phys Part-1, 42, 3503 (2003).

7) Tagaya A, Iwata S, Kawanami E, Tsukahara H, Koike Y, Appl Opt, 40, 3677 (2001).

8) Nobukawa S, Urakawa O, Shikata T, Inoue T, Macromolecules, 43, 6099 (2010).

9) Nobukawa S, Aoki Y, Yoshimura H, Tachikawa Y, Yamaguchi M, J Appl Polym Sci, 130, 3465 (2013).
10) Doi M, Pearson D, Kornfield J, Fuller G, Macromolecules, 22, 1488 (1989).

11) Nobukawa S. Molecular Dynamics and Orientation in Mixtures of Low-mass Molecules and Polymers. Dr. Thesis, (2011), Osaka University, Japan.

12) Nobukawa $S$, Hayashi $H$, Shimada H, Kiyama A, Yoshimura H, Tachikawa Y, Yamaguchi M, J Appl Polym Sci, 131, 40570 (2014).

13) Nobukawa S, Aoki Y, Fukui Y, Kiyama A, Yoshimura H, Tachikawa Y, Yamaguchi M, Polym J, 47, 294 (2015).

14) Abd Manaf ME, Tsuji M, Shiroyama Y, Yamaguchi M, Macromolecules, 44, 3942 (2011).

15) Yamaguchi M, Abd Manaf ME, Songsurang K, Nobukawa S, Cellulose, 19, 601 (2012).

16) Songsurang K, Shimada H, Nobukawa S, Yamaguchi M, Euro Polym J, 59, 105 (2014).

17) Jackson WJ, Caldwell JR, J Appl Polym Sci, 11, 211 (1967).

18) Ngai KL, Rendell RW, Yee AF, Plazek DJ, Macromolecules, 24, 61 (1991).

19) Miyagawa A, Korkiatithaweechai S, Nobukawa S, Yamaguchi M, Ind Eng Chem Res, 52, 5048 (2013).

20) Miyagawa A, Nobukawa S, Yamaguchi M, Nihon Reoroji Gakkaishi (J Soc Rheol Jpn), 42, 255 (2014).

21) Jho JY, Yee AF, Macromolecules, 24, 1905 (1991).

22) Inoue T, Nihon Reoroji Gakkaishi, 28, 167 (2000). (in Japanese)

23) Onsager L, J Am Chem Sci, 58, 1486 (1936).

24) Maeda M, Nobukawa S, Inomata K, Yamaguchi M, Nihon Reoroji Gakkaishi (J Soc Rheol Jpn), 47, 111 (2019).

25) Liu Y, Inglefield PT, Jones AA, Kambour RP, Magn Reson Chem, 32, S18 (1994).

26) Bergquist $\mathrm{P}, \mathrm{Zhu} \mathrm{Y}$, Jones AA, Inglefield PT, Macromolecules, 32, 7925 (1999).

27) Shafiee H, Tagaya A, Koike Y, Polym J, 43, 306 (2011).

28) Nobukawa $S$, Hasunuma $S$, Sako $T$, Miyagawa A, Yamaguchi M, J Polym Sci B Polym Phys, 55, 1837 (2017). 